\title{
Plurilingualism at risk. The Italian case
}

Silvia Minardi

\section{CpenEdition}

\section{Journals}

Electronic version

URL: http://journals.openedition.org/esp/431

DOI: 10.4000/esp.431

ISSN: 2532-0319

\section{Publisher}

Centre d'Information sur l'Éducation Bilingue et Plurilingue

\section{Printed version}

Date of publication: 1 December 2014

Number of pages: $35-43$

ISSN: 1127-266X

\section{Electronic reference}

Silvia Minardi, «Plurilingualism at risk. The Italian case », Éducation et sociétés plurilingues [Online] 37 | 2014, Online since 01 October 2015, connection on 02 May 2019. URL : http:// journals.openedition.org/esp/431 ; DOI : 10.4000/esp.431 


\section{PLURILINGUALISM AT RISK. THE ITALIAN CASE}

\section{Silvia MINARDI}

Le politiche linguistiche, a livello europeo, sottolineano la necessità di creare le condizioni, anche attraverso $i$ canali dell'educazione formale, perché $i$ repertori linguistici dei cittadini europei si trasformino in competenze. Il plurilinguismo, carattere fondante dell'identità di ogni cittadino europeo, ha bisogno di politiche educative volte a sostenerlo anche nel tempo. L'articolo esamina il caso dell'Italia e delle politiche linguistiche di questi ultimi anni caratterizzate da importanti decisioni frutto di diversi interventi di riforma della scuola.

Les politiques linguistiques au niveau européen soulignent la nécessite de créer les conditions, même dans l'éducation formelle, pour que les citoyens européens développent des compétences plurilingues à partir de leurs répertoires linguistiques. Le plurilinguisme, caractéristique fondamentale de l'identité de chaque citoyen européen, a besoin de politiques éducatives capables de le soutenir même dans le temps. L'article prend en considération le cas italien et les politiques linguistiques en Italie qui, depuis quelques années, a traversé une époque de reformes de son système scolaire.

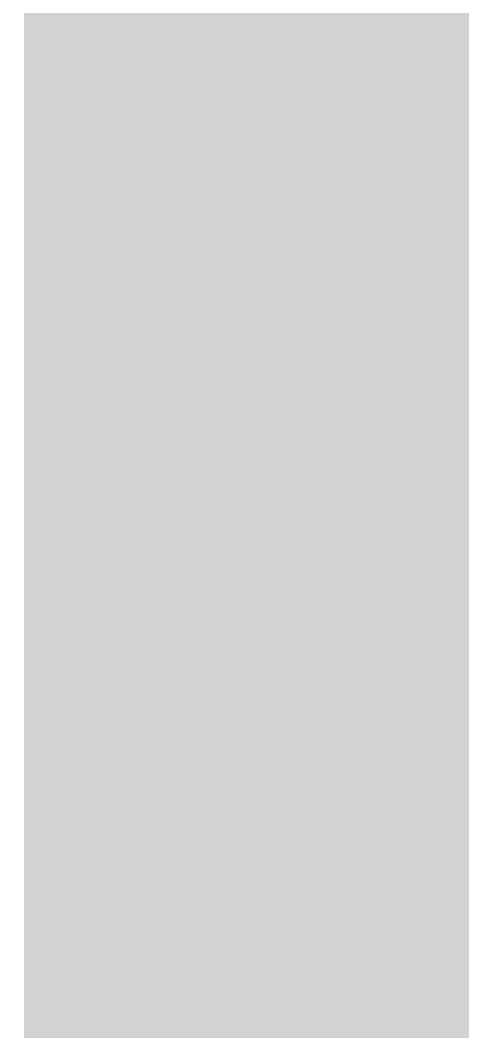

"Multilingualism is part and parcel of both European identity/citizenship and the learning society" (European Commission, 1995: 67).

W ithin the European context, both in the Europe of the 28 countries and in the Europe of the 47 countries (Council of Europe), language education plays a significant role for individuals and for societies as a whole. This was already evident in the EU White Paper Towards the learning society, published in 1995 .

Ever since the publication of the White Paper, language education has had several purposes:

- Proficiency in more than one language is a prerequisite if citizens of the European Union want to take advantage of the occupational opportunities open to them in a borderfree market. However, on a global market language proficiency is not enough without the ability to adapt to working and living environments characterized by differences in terms of languages and cultures.

- Proficiency in more than one language facilitates "interper- 
Plurilingualism at risk.

The Italian case

S. MINARDI

THE LANGUAGE OF INSTRUCTION

LANGUAGES AT SCHOOL. PRIMARY SCHOOL sonal, academic and social communication, expands intellectual horizons, and encourages appreciation and tolerance for different cultures" (Burbules \& Torres 2000: 21) and this is especially vital in an age of globalization and internationalization.

- Languages have always been the key to getting in touch with and understanding other people. Language proficiency helps to build up the feeling of belonging to a Europe which is characterized by cultural and linguistic diversity.

- Early language learning is an important factor in doing well at school.

In this contribution we will focus on the Italian situation and examine how the European guidelines have been applied to a context which has been the object of numerous reforms over the years.

The development of effective skills in the language of instruction are essential for successful learning across the whole curriculum.

The language of instruction in Italian schools is Italian, the national language which is also the mother tongue of the majority of students in Italian schools. However, $8.4 \%$ of the students in Italy have a different mother tongue (Alunni... 2013). Within the wider concept of plurilingualism and respect for linguistic diversity, the Indicazioni Nazionali per il curricolo della scuola dell'infanzia del primo ciclo di istruzione (Decreto Ministeriale 2012) - henceforth "National Guidelines 2012" - have attempted to address the needs of these learners with regard to competence in the language of instruction. The National Guidelines 2012 make it clear that plurilingual competences require the development of skills in different languages, i.e. the English language and a second foreign language, along with the learner's mother tongue and the language of instruction (1).

The National Guidelines are now being implemented and school curricula are being redefined with reference to them. At the beginning of the present school year (2013-2014) the Minister of Education launched a program of teacher training to help schools with the implementation of the new guidelines (http://www.indicazioninazionali.it/J/).

Foreign language learning was first introduced in Italian primary schools in 1977. The Italian Ministry of Education launched the ILSSE project (Insegnamento della Lingua Straniera nella Scuola 
Plurilingualism at risk. The Italian case

S. MinARDI elementare, foreign language teaching in primary schools), which ended in 1985 when a first reform of foreign language teaching in primary school was started. That reform introduced compulsory language teaching in all Italian schools following a model which the ILSSE project had developed. Its main features were:

- various foreign languages could be offered by the school, namely English, French, German, Spanish;

- learning aims and objectives were: developing the learner's cognitive skills; giving learners an instrument of communication with other people; starting to learn about other cultures;

- methodology: the sequence comprehension-production was suggested; the oral aspect is predominant and written production is introduced only at the end of primary school; the focus is on teaching and learning a wide range of vocabulary;

- organizational issues: three periods per week which had to be distributed over different days; foreign language teaching started in the second form (age 7); two categories of teachers were possible, i.e. the class teacher who was also in charge of foreign language teaching in his/her class and a specialized foreign language teacher who was only responsible for foreign language teaching to different classes.

This short presentation gives us an idea of the innovations of the project:

a) the concept of global language education and the implication that an initial approach to foreign language learning must take into account the gradual process of children's development;

b) the idea that communicative competence is only one goal alongside general cognitive development and fostering children's understanding of other cultures.

Among the issues which were to be tackled there was the need to train a great numbers of teachers with limited linguistic competences and to train them in new methodological approaches, which encouraged the development of teacher training courses and models over many years.

Much effort was made so as to promote language learning in primary education. But a political change was to occur in the country which also implied a drastic change in linguistic policies. In the years 2001-2006 a school reform started to change the Italian school system from its roots. It was inspired by the famous slogan of the three I's - "informatica" (Information technology), "inglese" (English) and "impresa" (business) - and was named after Ms. Moratti, the Italian Minister of Education at 
Plurilingualism at risk. The Italian case

S. MINARDI
FOREIGN

LANGUAGE TEACHING IN LOWER SECONDARY SCHOOL. the time. The school reform, which officially began in 2003 , introduced major changes in the Italian school system. As to language teaching, the most important decisions were the following:

- foreign language learning becomes mandatory in elementary education starting from the first year of primary school with one period per week in the first form, two periods in the second form and three periods per week in the next three years;

- English is the only official foreign language in all primary schools;

- English is taught by the teacher of the class with a B1 level certificate of English; if not, the teacher has to follow a training course with both face-to-face and online lessons. The course is intended to give primary school teachers the level of language proficiency which is required by law to teach pupils in primary schools;

- methodology: the Guidelines suggest "sensitizing the pupil to the use of the English language", i.e. they do not intend to enhance the formal learning of the language; they insist on the development of oral reception, interaction and production skills; what is recommended is the use of activities to enhance motivation (e.g. games). An interesting aspect is the suggestion to use English language learning in primary schools as a way to build a "language-friendly learning environment" and not as an aim in itself.

- expected competence levels: the levels of the Common European Framework are included in Decree 226/2005 and for primary schools, after a total time of 396 hours of English in five years, the expected competence level is Al. It is clear that a totally new era was starting for foreign language teaching in primary education. The development of language education - language skills are cross-curricular and cannot be confined to language teaching only - which was in the ILSSE project, has disappeared.

In November 2013 a decree was passed which would introduce English language teaching in pre-primary schools. The decision was made in order to promote plurilingualism in the Italian educational system (2).

As in primary education, the teaching of foreign languages in higher levels of schooling has also been the target of important changes throughout the years. 
Plurilingualism at risk. The Italian case

S. MINARDI
In 1979 only one foreign language was compulsory in middle schools (students aged 11-14). The languages which could be chosen were German, English, French and Spanish. The methodology which was in use implied activities on "language use" and the "integration" between foreign language teaching and mother tongue teaching, i.e. "the concrete use of the language in contextualized situations and not just the teaching of formal grammatical schemes. The use of the language in communicative contexts goes hand in hand with a thorough reflection on the morpho-syntactic, semantic and communicative aspects of the language [...] The linguistic analysis of different languages requires the use of a common terminology between the Italian mother tongue teacher and the teacher of the foreign language" (National Guidelines 1979, my translation). Once again the notion of language education figures in an official text.

It was in 1999 with the experimental project known as "Progetto lingue 2000" that a second foreign language started to be taught in lower secondary schools ( $c f$. Circolare Ministeriale 1998). The project was developed from 1999 to 2003 and completely changed the paradigm of language learning and teaching in Italy. According to the project, teachers were encouraged to develop speaking and listening skills and to evaluate and assess their students' competences using external certification. This project opened up the opportunity for more teacher training across the country. The most interesting innovations were:

- students could be grouped together according to their level of proficiency in one language and groups were made of 15 students at most;

- teaching was organised in a modular way, which implied reorganizing the school timetable so as to concentrate time in teaching modules of 20-30 hours;

- oral skills were predominant;

- the use of ICTs in foreign language teaching and learning was encouraged;

- a massive plan of language teacher training was launched.

Of all this very little survives in the school reform of 2003. The second language becomes mandatory (with 66 hours/year) and English is the first foreign language compulsory for all students throughout the country (with 99 hours/year). All this was accompanied by a massive press campaign, promoted by the Ministry of Education and based on the assumptions that:

a) if you want to learn a language you have to learn it for a 
Plurilingualism at risk.

The Italian case

S. MINARDI

FOREIGN LANGUAGE TEACHING IN UPPER SECONDARY SCHOOLS. long time (English is now taught in all schools and studied by all Italian students from the age of 6 to the age of 19);

b) there is only one language which is really necessary in a globalized world and that is English.

In Italy, the Upper Secondary School system includes the Liceo (academic high schools) and the vocational training schools. The Liceo system lasts five years and includes eight different types of schools. The Reform for the Liceo system was approved on 4 February 2010. Press campaigns and official statements insisted on a greater presence of foreign languages in Italian schools. But the reality soon proved to be different. All Liceo schools have to teach "a foreign language and culture". It is true there is no specific reference to English which might mean each student is free to choose the foreign language he/she wants. But in reality, in all Liceo schools only one foreign language is mandatory and English is chosen by the vast majority of students - official declarations did not encourage different choices (3). The "Liceo Linguistico" is the only one in which students can learn three foreign languages for five years. As to the "Liceo delle Scienze Umane" it includes a second foreign language in the economic pathway. A second foreign language is not to be taught in any of the other "Liceo" schools and if we examine the situation in detail we will see that even if English is now learnt in the great majority of upper secondary schools, the time allocated to English in the core curriculum has been reduced.

In all technical schools English is learnt for five years and 99 hours/year. There is a second foreign language in the core curriculum in some pathways (management, accountancy, marketing). In the tourism pathway there is also a third language which is mandatory during the last three years.

As to vocational training schools, a second foreign language figures in the core curriculum of some pathways only (social services, business services, and a few others).

What is generally valid in all upper secondary schools is an important reduction in the amount of allocated time within the core curriculum for foreign language learning.

As to teaching processes and methodology, Italian education authorities refer to the Common European Framework in the official guidelines establishing minimum levels of attainment for foreign languages that correspond to the proficiency levels defined 
Plurilingualism at risk.

The Italian case

S. MINARDI
CLIL CONTENT

AND LANGUAGE

INTEGRATED

LEARNING) and described in the CEFR. The required competence levels in Italian schools are given below:

Type OF School Level

TOTAL NUMBER OF HOURS

EXPECTED COMPETENCE

primary school

396 - English

$\mathrm{A} 1$

lower secondary school

297 - English

A2

198 - second

foreign language

$\mathrm{Al}$

upper secondary school

(with the exception

330 - English

B2

330 - second F.L.

B1

of the Liceo Linguistico)

upper secondary school (Liceo Linguistico)

$\begin{array}{ll}528 \text { - English } & \text { B2 } \\ 660 \text { - second F.L. } & \text { B2 } \\ 528 \text { - third F.L. } & \text { B1 }\end{array}$

Before the reform of secondary education, CLIL developed, in Italy, as a bottom-up process: teachers all around the country and in all types of schools had implemented CLIL in different ways also thanks to regional or local training projects. With the reform, a top-down process has started. All students in the last year of upper secondary education are obliged to learn one non-language subject through a foreign language. In the Liceo Linguistico (the language pathway) CLIL in a foreign language begins in the third year and CLIL in a different foreign language in the fourth year.

The CLIL teacher in Italy is a non-language teacher. The new regulations on initial teacher training (Decreto 10.09.2010, nr 249) establish that the CLIL teacher (art. 14) has a language competence of level C1 and is ready to follow a post-graduate course of around 1,500 hours including 300 hours training. For the time being, the main issue is the scarcity of non-language teachers with the required C1 level language competence. As a temporary measure, it has recently been decided to activate language courses for non-language teachers who have a level $\mathrm{B} 1$ so as to let them achieve level B2. 
Plurilingualism at risk.

The Italian case

S. MINARDI

\section{CONCLUSION}

\section{REFERENCES}

The most widely learnt foreign language in Italy is French both in lower secondary education (72.3\%) and in pre-vocational/vocational and general upper secondary education (26.7\%). Spanish comes next (18.8\%) in lower secondary education but not in prevocational/vocational and general upper secondary education $(5.8 \%)$, where German is more widely learnt $(7.3 \%)$. German holds the position of the third most learnt language in lower secondary education $(8.7 \%)$.

In the Italian school system only the English language is mandatory throughout the years of compulsory education. All pupils enrolled in primary education learn English. In lower secondary education more than $80 \%$ of students learn two foreign languages. In general upper secondary education less than $30 \%$ of students learn two or more foreign languages. The percentage is higher in pre-vocational and vocational upper secondary education (Eurydice/Eurostat 2012).

If we take into account the European Parliament resolution of 24 March 2009 on Multilingualism: an asset for Europe and a shared commitment which

"(i) considers that Europe's linguistic diversity constitutes a major cultural asset and it would be wrong for the European Union to restrict itself to a single main language"; and

(ii) "emphasizes the vital need to provide special attention and support at school to pupils who cannot be educated in their mother tongue, and warmly welcomes the Commission proposal to promote "mother tongue plus two' in education" (4),

In a word, if we consider these two declarations, it is clear that Italy is far behind: plurilingualism in the Italian education system is seriously at risk.

Alunni con cittadinanza non italiana. Approfondimenti e analisi. 2013. Rapporto nazionale A.S. 2011/2012, Quaderni ISMU 1/2013, Fondazione ISMU e MIUR DG per lo Studente, l'Integrazione, la partecipazione e la comunicazione.

BURBULES N. \& TORRES G. (eds.). 2000. Globalization and Education: Critical perspectives. Routledge, New York.

Circolare Ministeriale. 1998. Progetto lingue 2000, 10 luglio, nr. 304.

Eurydice/Eurostat. 2012. Key data on teaching languages at school in Europe. Brussels: Eurydice/Eurostat.

European Commission. 2012a. First European survey on language competences. Final report. Strasbourg: EG. [Online: 


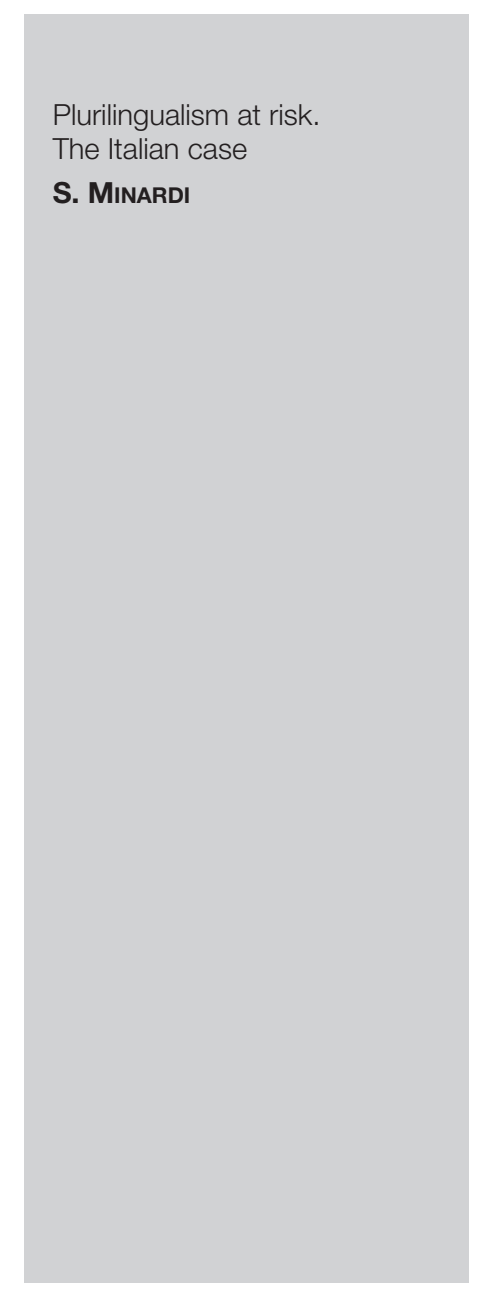

http://ec.europa.eu/languages/eslc/index.html]

European Commission. 2012b. Language competences for employability, mobility and growth. Strasbourg: EC.

European Commission. 2012c. Language competences for employability, mobility and growth. Commission staff working document. Strasbourg: EC.

Indicazioni Nazionali per il curricolo della scuola dell'infanzia del primo ciclo di istruzione. 2012. Decreto Ministeriale 16.11.2012 nr. 254/2012.

Recommendation GM/Rec(2014)5 of the Committee of Ministers to member States on the importance of competences in the language(s) of schooling for equity and quality in education and for educational success (Adopted by the Committee of Ministers on 2 April 2014 at the 1196th meeting of the Ministers' Deputies).

SCHLEICHER A. (ed.). 2012. Preparing Teachers and Developing School Leaders for the 21st Century: Lessons from around the World, OECD Publishing.

\section{FOOTNOTES}

(1) "l'apprendimento della lingua inglese e di una seconda lingua comunitaria, oltre alla lingua materna e di scolarizzazione, permette all'alunno di sviluppare una competenza plurilingue e pluriculturale e di acquisire i primi strumenti utili ad esercitare la cittadinanza attiva nel contesto in cui vive, anche oltre i confini del territorio nazionale", Decreto Ministeriale 16.11.2012 nr 254/2012, p. 9.

(2) The text which was approved introduced the promotion of plurilingualism through English language teaching ("promuovendo il plurilinguismo attraverso l'acquisizione dei primi elementi della lingua inglese"), cf. legge 128/2013 recante: "Misure urgenti in materia di istruzione, università e ricerca" (13A09118) (Gazzetta Ufficiale, Serie Generale n. 264 del 11-11-2013).

(3) At the time, Ms Letizia Moratti, the Education Minister, declared that "if a young person studies English for thirteen years he/she is bound to reach a mother tongue level of proficiency".

(4) http://www.europarl.europa.eu/sides/getDoc.do?pubRef=-//EP//TEXT+TA+P6-TA2009-0162+0+DOC+XML+V0//EN 